\title{
Brainstem cavernous malformation
}

Joel Woodley-Cook, ${ }^{1}$ Lyne Noel de Tilly, ${ }^{2}$ Loch MacDonald ${ }^{3}$

1 Department of Medical Imaging, University of Toronto, Toronto, Canada

${ }^{2}$ Department of Medical Imaging, St Michael's Hospital Toronto, Canada

${ }^{3}$ Department of Neurosurgery, St Michael's Hospital, Toronto,

\section{Correspondence to}

Dr Joel Woodley-Cook jwoodleycook@gmail.com Canada

A 50-year-old man presented to the emergency department with a 4-week history of worsening ataxia. CT (figure 1) and MRI (figures 2 and 3) demonstrated a lobulated lesion of varying densities on CT and signal intensities on MRI ('popcorn' ball apperance) in keeping with different stages of haemorrhage in his midbrain and pons. There was no evidence of hydrocephalus (figure 4). He was admitted under the neurosurgical service and

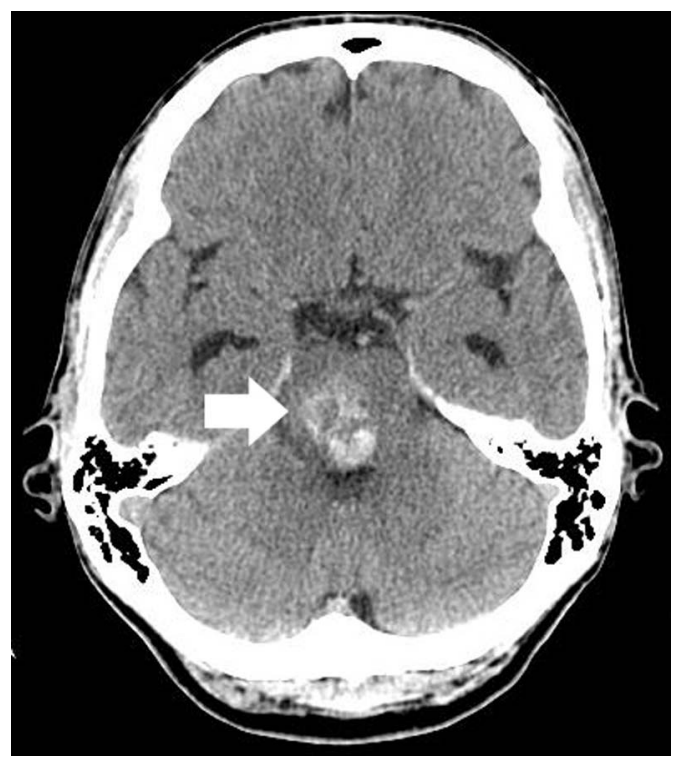

Figure 1 Axial non-enhanced CT of the head demonstrating a heterogeneously hyperdense expansile lesion in the midbrain, consistent with varying ages of haemorrhage (arrow).

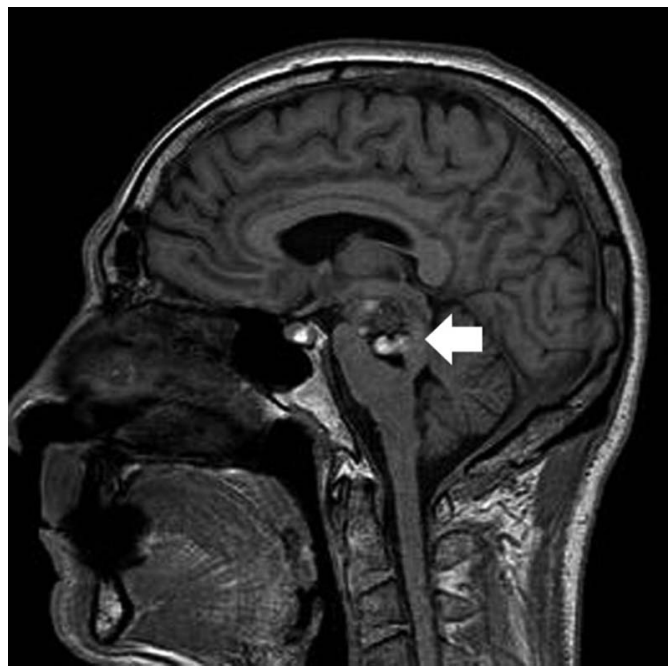
Noel de Tilly L MacDonald L. BMJ Case Rep Published online: [please include Day Month Year] doi:10.1136/bcr-2012007679

Figure 2 Sagittal non-enhanced T1-weighted MRI of the head demonstrating a lobulated heterogeneous lesion in the midbrain and pons, consistent with varying ages

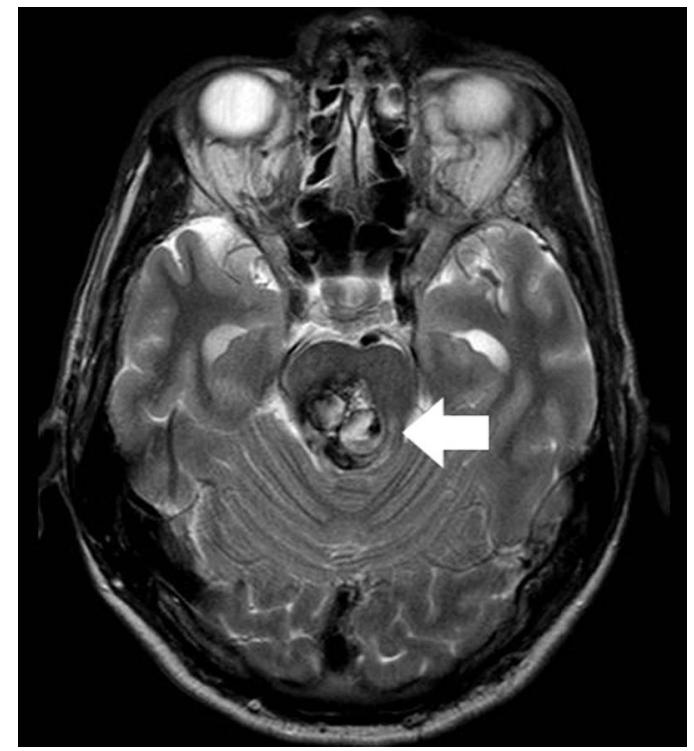

Figure 3 Axial T2-weighted MRI of the head showing an expansile, lobulated lesion of heterogeneous signal intensities within the midbrain, in keeping with varying stages of haemorrhage (arrow). This imaging finding is the typical 'popcorn ball' appearance that is frequently used in the literature to describe a cavernous malformation.

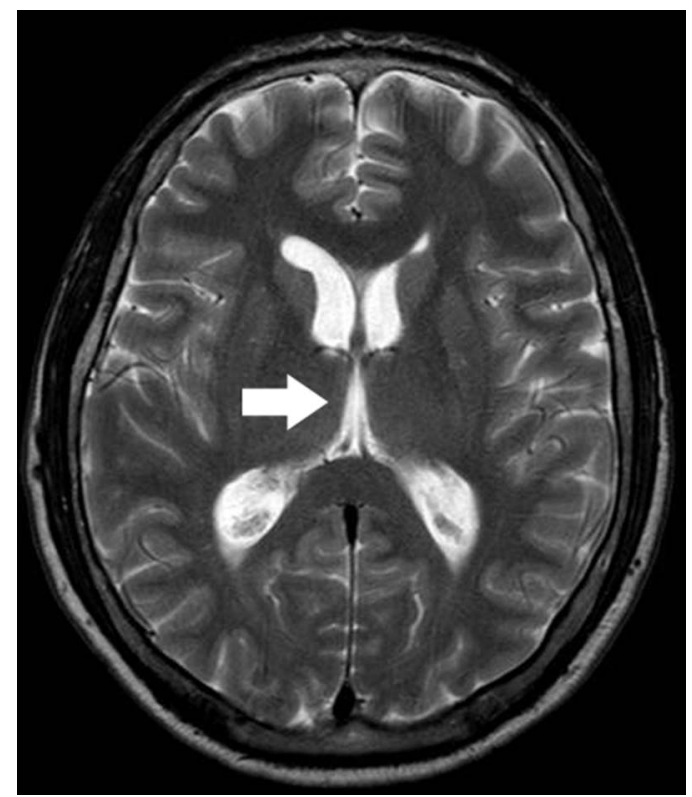
of haemorrhage (arrow).
Figure 4 Axial T2-weighted MRI of the head demonstrating a normal third ventricle (arrow). 


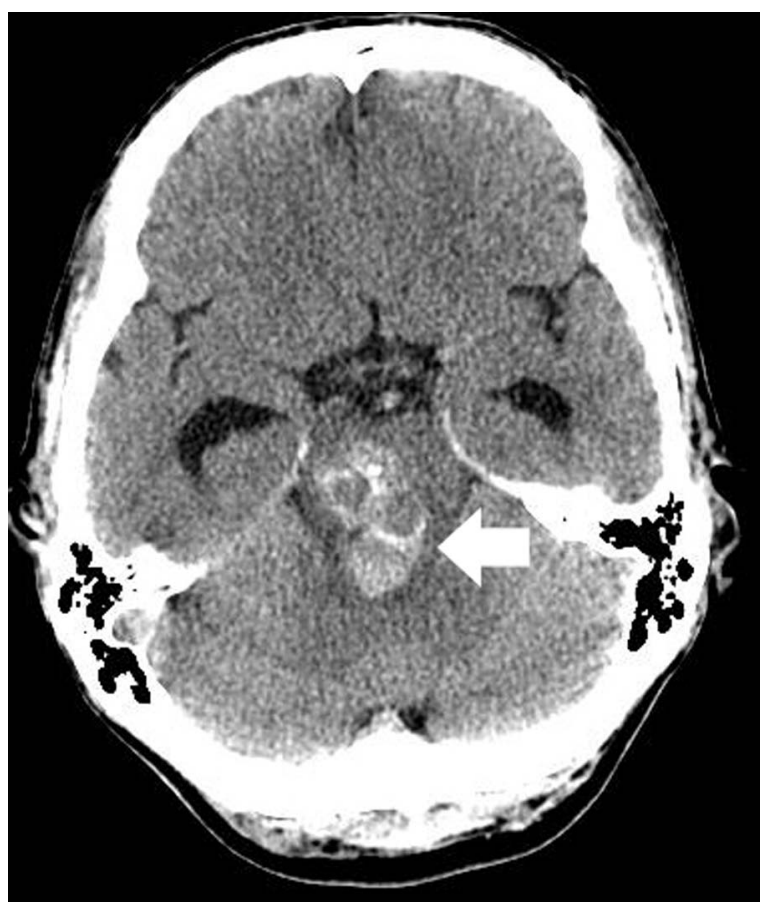

Figure 5 Axial non-enhanced CT of the head demonstrating an interval increase in the size of haemorrhage within the midbrain (arrow).

within 2 days, his ataxia worsened and he developed a new clinical finding of diplopia. Repeat CT (figure 5) and MRI demonstrated an increase in the size of his brainstem haemorrhage with interval development of hydrocephalus and transependymal flow of cerebral spinal fluid (figure 6).

This imaging appearance is in keeping with a cavernous malformation (aka 'cavernoma'). These are benign vascular hamartomas without neural tissue that contain haemorrhage-filled vessels that may be associated with calcifications. ${ }^{1}$ Their approximate prevalence is $0.5 \%$ with men and women being equally affected. ${ }^{2}$ The Zabramski classification of cavernous malformations divides these lesions into four types: (1)subacute haemorrhage, (2) degrading haemorrhage of various ages, (3)chronic haemorrhage and (4)punctate microhaemorrhages. These lesions may be associated with developmental venous anomalies, superficial siderosis, cutaneous cafe au lait spots or hyperkeratotic capillaryvenous malformations (aka 'cherry angiomas'). ${ }^{2}$

Owing to his worsening clinical symptoms and hydrocephalus, surgical resection was performed and surgical pathology confirmed a cavernous malformation of the brainstem.

Since surgical resection, this patient's ataxia and diplopia have improved.

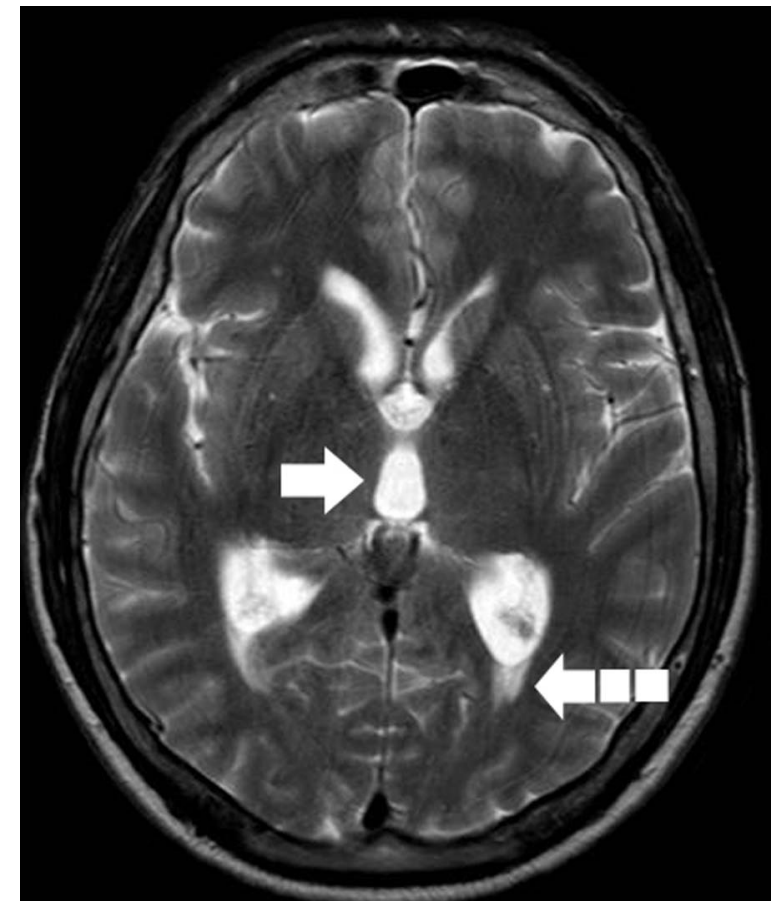

Figure 6 Axial T2-weighted MRI of the head demonstrating interval expansion of the third ventricle (arrow) and transependymal flow of cerebral spinal fluid (dashed arrow), consistent with hydrocephalus.

\section{Learning points}

- Cavernous malformations are benign hamartomas containing haemorrhage-filled blood vessels, void of neural tissue.

- Classic imaging appearance on MRI is a non-enhancing 'popcorn' ball appeareance of varying signal intensities, representing various stages of haemorrhage.

- These lesions may be observed if clinically silent.

Contributors The manuscript has been written by JW-C. NY and MD have proofread and edited the article.

Competing interests None.

Patient consent Obtained.

Provenance and peer review Not commissioned; externally peer reviewed.

\section{REFERENCES}

1 Rivera PP, Willinsky RA, Porter PJ. Intracranial cavernous malformations. Neuroimaging Clin N Am 2003;13:27-40.

2 Biondi A, Clemenceau S, Dormont D, et al. Intracranial extra-axial cavernous (HEM) angiomas: tumors or vascular malformations? J Neuroradiol 2002;29:91-104.

Copyright 2013 BMJ Publishing Group. All rights reserved. For permission to reuse any of this content visit http://group.bmj.com/group/rights-licensing/permissions.

BMJ Case Report Fellows may re-use this article for personal use and teaching without any further permission.

Become a Fellow of BMJ Case Reports today and you can:

- Submit as many cases as you like

- Enjoy fast sympathetic peer review and rapid publication of accepted articles

- Access all the published articles

- Re-use any of the published material for personal use and teaching without further permission

For information on Institutional Fellowships contact consortiasales@bmjgroup.com

Visit casereports.bmj.com for more articles like this and to become a Fellow 